\title{
Control of ophidism in Brazil: a model for Africa
}

\section{Chippaux J-P (1)}

(1) Research Director, Unit "Mother and Child Health in the Tropics", Research Institute for Development, Paris, France.

Envenomation is an important public health problem in most developing countries. Snakebites tend to be neglected throughout the globe, but particularly in subSaharan Africa where, although frequent $(500,000$ envenomations and 30,000 deaths a year), the medical authorities seem to be unaware of them and unable to implement control measures or management of the bites (1).

In industrialized countries, the situation is less serious due to the following factors, individually or in combination: snakes are rarer, especially in Europe; human activities limit the human-snake encounters; and health services provide correct management of envenomations.

On the other hand, in a few tropical countries, envenomations are regarded as a national matter in relation to the epidemiological situation. As a member of this group, Brazil may provide a useful and valuable example for African countries.

Ophidism has been reported in Brazil for almost a century and has been the subject of long-standing scientific studies. A few years after the discovery of antivenoms by Phisalix and their development by Calmette, Vital Brazil started to manufacture antivenoms in São Paulo (2). In his book A Defesa contra o Ophidismo (3), published in 1911 and translated into French in $1914^{*}$, Vital Brazil estimated that the annual incidence of snakebites in Brazil was 18,200 and resulted in 4,800 deaths. He deduced from these data, for the very first time, the economic and social burden of ophidism. Moreover, he proposed a national control program based on the exchange of morbidity information or snakes themselves for antivenom vials and injection

\footnotetext{
* The translation into French paid homage to Calmette, but also intended to spread abroad the work of the Butantan Institute in "an accessible language". Today, of course, it would be translated into English.
} 
equipment. The mobilization for this national cause was considerable and included: public institutions that supported the antivenom manufacture, railroad companies that facilitated the transport of snakes and antivenoms, as well as farmers and individuals, who actively took part in the control of ophidism. Vital Brazil also planned the establishment of offices in each Brazilian state capital to control ophidism, particularly in remote areas where he thought the incidence was relatively high. Despite these efforts, the creation of an efficient envenomation reporting system was difficult (4).

The existence of effective accessible antivenoms was certainly a determining element in this successful story. It aided an early medical treatment for envenomations; however, in several Brazilian regions, there are still some barriers to benefiting from this treatment.

In Brazil, antivenoms are still produced by public manufacturers - or supported by public subsidies - resulting in their reasonable cost and broad use by patients, even the poorest.

It was a priority to evaluate the necessity for antivenoms based on snakebite incidence. In the beginning of the $20^{\text {th }}$ century, one of the main objectives was to give antivenom in exchange for snakes needed to obtain venoms, or medical information that allowed not only improvement, but also more extensive distribution of the product. The number of cases was probably underestimated for many decades. According to the latest epidemiological data, the annual incidence has reached approximately 30,000 envenomations, but the case-fatality rate has decreased dramatically, below $0.5 \%$ on account of rapid and effective treatments (5). In spite of the increasing population, it seems that the number of cases has remained stable during the century, if we accept Brazil's official estimates. However, during recent years, the snakebite incidence has increased, which can be explained partly by ecological and economic changes, in particular Amazon deforestation, and by a significant improvement of the medical reporting system during the last decade.

Studies on venoms and on the epidemiology and treatment of envenomations were also a very important and useful factor. Lastly, the publication of a specialized journal, the first to be offered free on the Internet, facilitates the diffusion of information and stimulates additional research.

Africa is still very isolated and should follow this example to escape from the catastrophic situation concerning snakebites and scorpion stings, respectively in subSaharan and northern Africa. Independently of financial and technological support, 
always welcomed, the model provided by Brazil could stimulate Africa to improve its disastrous situation.

\section{REFERENCES}

1. Chippaux JP. Snake bites: appraisal of the Global situation. Bull World Health Organ. 1998;76(5):515-24.

2. Hawgood BJ. Pioneers of anti-venomous serotherapy: Dr. Vital Brazil (1865-1950). Toxicon. 1992;30(5-6):573-9.

3. Brazil V. A defesa contra o ophidismo. São Paulo: Pocai \& Weiss; 1911.

4. Bochner R, Struchiner CJ. Recording of venomous bites and stings by National Information Systems in Brazil. Cad Saude Publica. 2002;18(3):735-46.

5. Brasil. Ministério da Saúde. Sistema de Informação de Agravos de Notificação (SINAN). Casos de acidentes por serpentes. Brasil, Grandes Regiões e Unidades Federadas. 2000 a 2009. Brasília: Ministério da Saúde; 2000-2009 [cited 2010 March 3].

Available

from:

http://portal.saude.gov.br/portal/arquivos/pdf/casos acidentes serpentes bra 00a09 tabela.pdf.

\section{CORRESPONDENCE TO:}

JEAN-PHILIPPE CHIPPAUX, Institut de Recherche pour le Développement (UMR 216), IRD, 08 B.P. 841, Cotonou, Bénin. Phone : +229 21309821. Fax : (229) 2130 8860. Email: jean-philippe.chippaux@ird.fr. 